\title{
Pulmonary melanoma and "crazy paving" patterns in chest images: a case report and literature review
}

\author{
Yikuan Feng ${ }^{\dagger}$, Jianping Zhao ${ }^{\dagger}$, Qun Yang, Weining Xiong, Guohua Zhen, Yongjian Xu, Zhenxiang Zhang
} and Huilan Zhang ${ }^{*}$

\begin{abstract}
Background: In the lung, melanoma is mostly arranged as patterns of multiple nodules, solitary nodules, or miliary invasions. Very rarely, it also displays a "crazy paving" pattern (also described as a "paving stone," "flagstone," or "slabstone" pattern), which is rarer still in discrete bilateral nodules. This pattern is considered to be caused by pulmonary alveolar proteinosis, but its association with various diseases is unclear.

Case presentation: A 60-year-old man was diagnosed with pulmonary melanoma. Computed tomography revealed discrete bilateral nodules surrounded by a "paving" pattern. A literature review found more than 40 types of diseases that have presented with "paving" patterns in the lung - predominantly pulmonary alveolar proteinosis, viral pneumonia, exogenous lipoid pneumonia, bacterial pneumonia, pulmonary alveolar microlithiasis, interstitial pneumonia, ARDS, squalene aspiration pneumonia, radiation pneumonitis, drug-induced pneumonitis, pulmonary leptospirosis, pulmonary hemorrhage, and pulmonary nocardiosis.

Conclusions: We describe the first case of pulmonary melanoma in the form of discrete bilateral nodules accompanied with a computed tomography paving pattern. Although pulmonary paving patterns are rare, more than 40 diseases reportedly display them; clinicians should consider melanoma of the lung in differential diagnoses for patients who show such a pattern.
\end{abstract}

Keywords: Pulmonary, Melanoma, Crazy paving, Case report

\section{Background}

Melanoma accounts for approximately $75 \%$ of deaths from skin cancers, and has an increasing incidence rate $[1,2]$. Although it can invade all organs, the lung is the most frequently involved, with a $70-87 \%$ incidence rate of metastatic invasion [3, 4]. Melanoma in the lung is mostly metastatic, and usually forms patterns of multiple nodules, solitary nodules, or miliary invasions. Diffuse pulmonary infiltration together with discrete bilateral nodules is an exceedingly scarce pattern. Here, we describe the first case, to our knowledge, of melanoma infiltrating the lung in the pattern of bilateral discrete nodules accompanied with surrounding "crazy paving"

\footnotetext{
* Correspondence: huilanz_76@163.com

${ }^{\dagger}$ Equal contributors

Department of Respiratory and Critical Care Medicine, Tongji Hospital, Tongji Medical College, Huazhong University of Science and Technology, Wuhan 430030, China
}

(c) 2016 The Author(s). Open Access This article is distributed under the terms of the Creative Commons Attribution 4.0 International License (http://creativecommons.org/licenses/by/4.0/), which permits unrestricted use, distribution, and reproduction in any medium, provided you give appropriate credit to the original author(s) and the source, provide a link to the Creative Commons license, and indicate if changes were made. The Creative Commons Public Domain Dedication waiver (http://creativecommons.org/publicdomain/zero/1.0/) applies to the data made available in this article, unless otherwise stated. lesions in computed tomography (CT) images. We also review the literature on this imaging pattern (also described as a "paving stone," "flagstone," and "slabstone" pattern) and its association with various diseases.

\section{Case presentation}

A 60-year-old Asian man with a smoking history of more than 120 pack-years presented to our department with complaints of intermittent dry cough, hemoptysis, suppression of chest, and dyspnea for 3 months. He denied fever, weakness, or weight loss. Two months before admission to our department, the patient received a 2-week course of antibiotic therapy that showed no effectiveness.

On presentation, the patient was a well-nourished man with temperature of $36.5{ }^{\circ} \mathrm{C}$, blood pressure of $105 /$ $60 \mathrm{mmHg}$, pulse rate of 65 beats/min, respiratory rate of 19 breaths/min, and oxygen saturation of $92 \%$ on ambient 
air. Arterial blood gas analysis showed $\mathrm{PaCO}_{2} 43 \mathrm{mmHg}$, $\mathrm{PaO} 266 \mathrm{mmHg}$, and $\mathrm{SaO} 292 \%$. Auscultation of his chest revealed decreased breath sounds and fine crackles bilaterally, but more notably in the left lower lung. He showed no evidence of suspicious pigmented lesions of the skin, mucosa, or eyes; the rest of the physical examination was unremarkable.

His complete blood count showed a mild anemia level of hemoglobin $9.8 \mathrm{~g} / \mathrm{dL}$ and mild leukocytosis with a white blood cell count of $10.46 \times 109 / \mathrm{L}$ and neutrophils at $7.72 \times 109 / \mathrm{L}$. Metabolic panel was normal except for a serum potassium level of $2.89 \mathrm{mmol} / \mathrm{L}$. Serum tumor markers, including CEA, SCC, CYFRA21-1, NSE, AFP, CA19-9, and CA72-4, were all normal. Serum antinuclear antibody test, anti-neutrophil cytoplasmic antibody test, thyroid function test, erythrocyte sedimentation rate, and T-SPOT were also all negative, as were tests for hepatitis, syphilis, and HIV. Serum lactate dehydrogenase was not detected. A pulmonary function test showed that his pulmonary ventilation function and diffusing capacity for carbon monoxide (DLco) were in normal reference ranges. Fractional exhaled nitric oxide concentration was $3.6 \mathrm{ppb}$.

A postero-anterior chest radiograph showed bilateral nodules and bilateral fibrotic lesions (Fig. 1). An enhanced CT scan of the chest showed bilateral consolidations with a $28-\mathrm{mm} \times 24-\mathrm{mm}$ nodule on the right upper lobe and a 33-mm $\times 43-\mathrm{mm}$ subpleural nodular mass on the left lower lobe, accompanied with surrounding bilateral "paving" lesions (Fig. 2). Increased and enlarged lymph nodes in the right hilar, mediastinum, and left axillary fossa were noted. The CT scan also showed bilateral pleural thickening, fibrotic changes, and bilateral pleural effusions. The CT scan taken at the local hospital two months before admission to our department presented a similar imaging but with smaller nodules (A $27 \mathrm{~mm} * 24 \mathrm{~mm}$ nodule on the right upper lobe and a $30 \mathrm{~mm}^{*} 21 \mathrm{~mm}$ mass on the left lower lobe) surrounded by "paving" lesions.

On presentation, the patient was treated with cefoperzone sodium/tazobactam and levofloxacin in case of pulmonary bacterial infection, which eventually showed no effectiveness. He then underwent a CT-guided fine needle aspiration biopsy from the left lung, which revealed pleomorphic cells with components of pigment granules. Immunohistochemical (IHC) staining was positive for human melanoma black-45 (HMB-45), Melan-A, and Ki-67 (LI $30 \%$ ), whereas staining for S-100 protein (Fig. 3), cytokeratin (CK5/6, CK7), CD68, CD56, P63, TTF-1, P40, Napsin A, ALK D5F3, ALK D5F3 N, Syn, and CgA were negative.

On establishing the diagnosis of melanoma, the patient refused chemotherapy or surgery for lack of money. He died two months later.

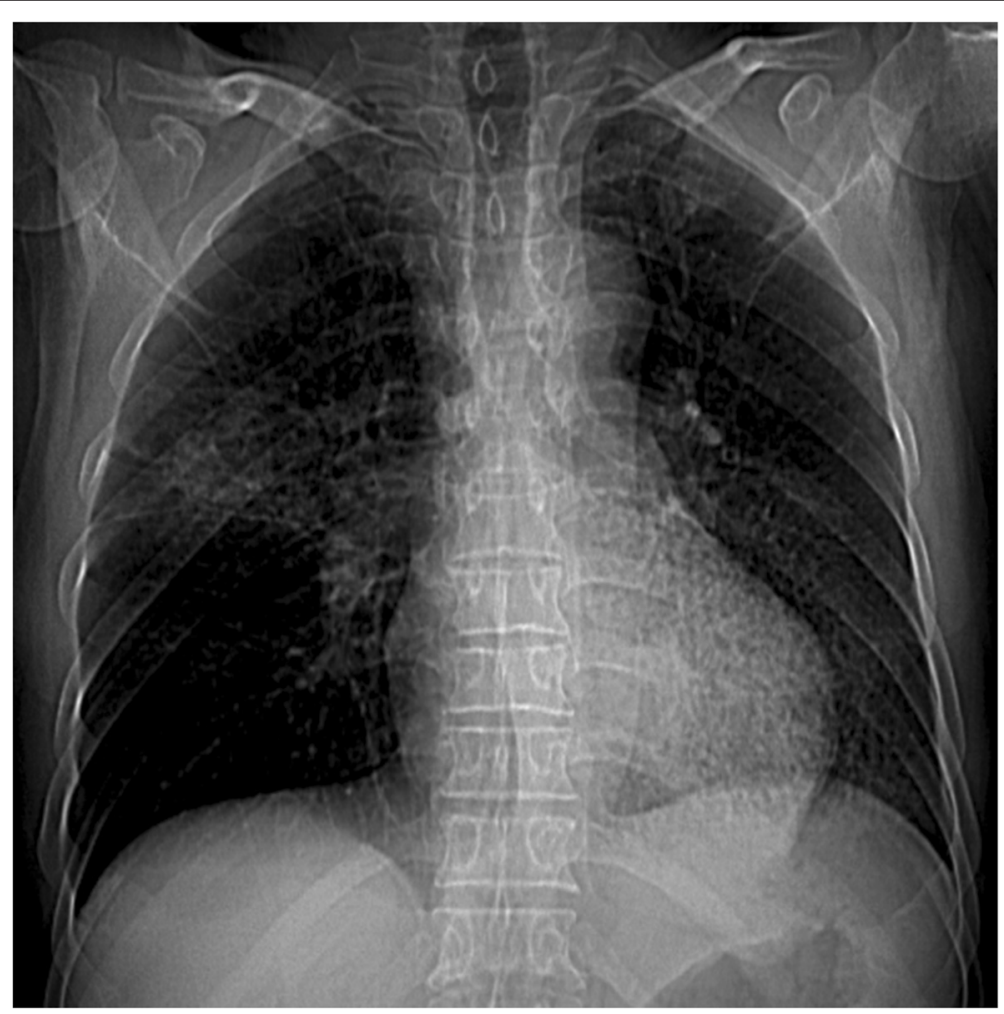

Fig. 1 Chest imaging. Chest X-ray shows multiple bilateral nodules with surrounding bilateral reticular fibrotic lesions 


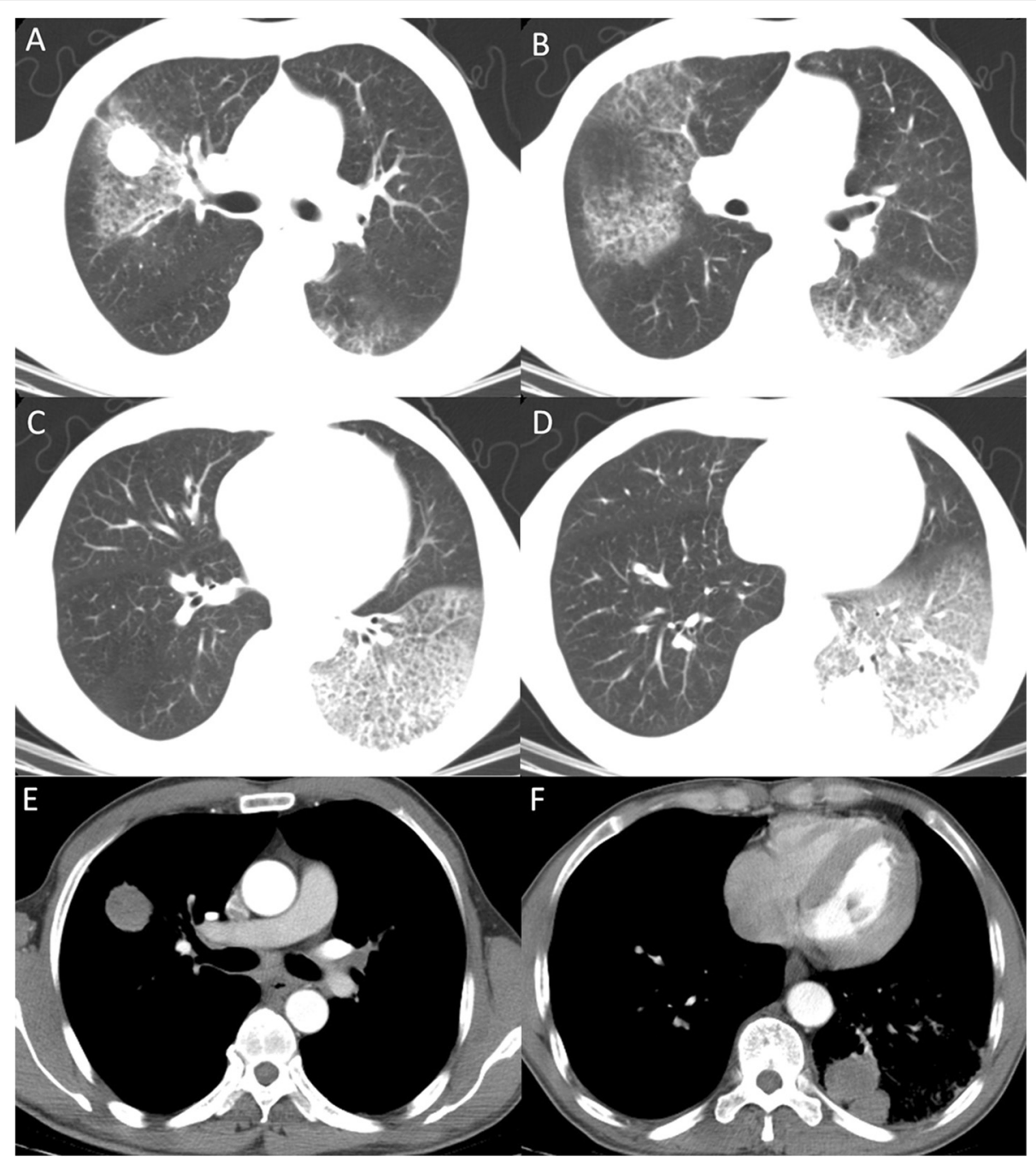

Fig. 2 Sixty-year-old man with discrete bilateral nodules with surrounding "paving" pattern. Computed tomography (CT) enhancement scan shows discrete bilateral consolidations with a 28-mm $\times 24-\mathrm{mm}$ nodule on the right upper lobe $(\mathbf{a}, \mathbf{e})$ and a 33-mm $\times 43-\mathrm{mm}$ subpleural mass with slightly uneven enhancement on the left lower lobe $(\mathbf{d}, \mathbf{f})$, accompanied with intralobular interstitial thickenings shown as a surrounding bilateral paving pattern (b, $\mathbf{c})$

\section{Discussion}

Although melanoma can invade all organs of the human body, the lung is the most common site of metastasis, and respiratory failure caused by metastatic lesions is the most common cause of death in patients with melanoma [3]. Melanomas in the lung are mostly metastatic; primary melanoma of the lung accounts for only $0.01 \%$ of all primary pulmonary tumors [5]. Most patterns of pulmonary melanoma are solitary nodules, multiple nodules, and miliary peripheral pulmonary nodules; the miliary pattern implies a grave prognosis [4]. Few Englishlanguage reports of melanoma metastases to the lungs report nodules accompanied with diffuse infiltrates; fewer still describe any as discrete bilateral nodules with surrounding "paving" lesions.

Pulmonary lesions with paving patterns are usually diagnosed as pulmonary alveolar proteinosis (PAP). Although melanoma is rarely considered for such cases, paving patterns have been found in pulmonary melanoma. Shin et al. reported a diffuse infiltrative pattern consisting of intralobular interstitial thickenings and areas of ground-glass opacity in a pulmonary melanoma case, which was much like "paving" [6]. Kalchiem-Dekel et al. also presented a diffuse interstitial metastatic "paving" pattern in the lung in a 51-year-old male patient [7]. Although "paving" surrounding a mass has been found in pulmonary adenocarcinoma [8] and PAP [9], it has not been previously associated with melanoma, making our case the first description of invasive pulmonary melanoma manifested as bilateral discrete nodules with a surrounding "paving" pattern.

The patient had no history of excision of a cutaneous, mucosal, or ocular lesion, no evidence of suspicious pigmented lesions of the skin, mucosa, or eyes. He had no 


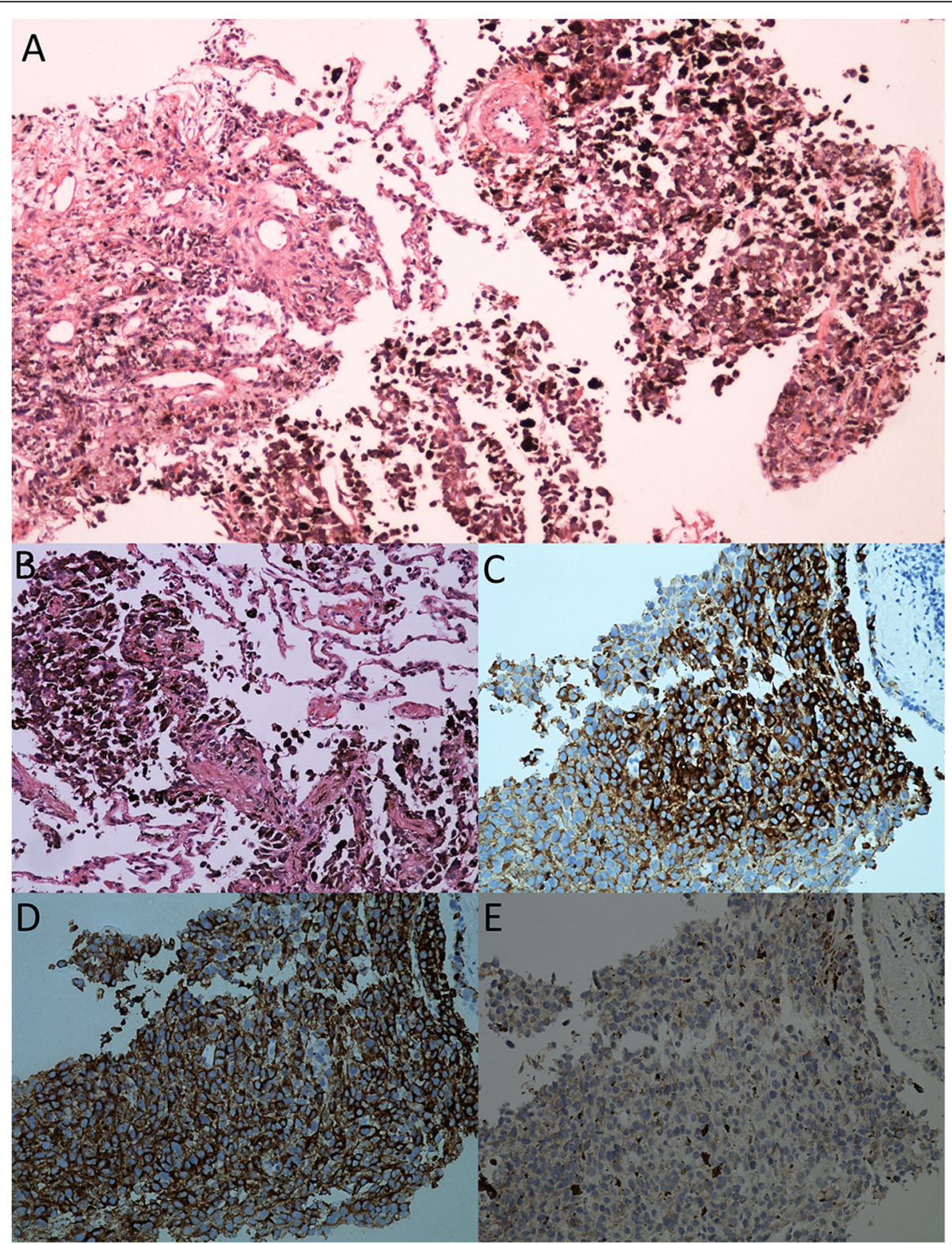

Fig. 3 Immunohistochemical (IHC) findings of computed tomography-guided fine-needle aspiration. Histopathological examination of biopsy shows perivascular and intra-alveolar accumulated pigmented cells containing melanin granules (hematoxylin and eosin, $\times 100)(\mathbf{a})$. Histopathological features of intra-alveolar atypical cell accumulation accompanied with interstitial thickenings; pleomorphic cells with atypia are pigmented deep brown and were diagnosed as melanocytes (hematoxylin and eosin, $\times 200$ ) (b). IHC staining for Melan-A is positive (original magnification $\times 200)(\mathbf{c})$. All tumor cell cytoplasm and focal nuclei show positive IHC staining for HMB-45 (original magnification $\times 200)(\mathbf{d})$. IHC staining for S-100 is negative (original magnification $\times 200)(\mathbf{e})$

evidence of metastasis from any organs that can be examined. Even though, we could not calssify this case as a primary melanoma of lung as he could not fully meet the clinical criteria set forth by Jensen and Egedorf [10], especially when the patient had bilateral pulmonary lesions and did not went on an autopsy after death. What accords this case peculiarity is the pulmonary imaging pattern of melanoma, regardless of primary or metastatic involvement.
Another peculiarity of this case is that the biopsy was negative for S-100 protein in IHC staining. S-100 protein, along with HMB-45 and Melan-A, is a characteristic marker for melanocytes. Although melanoma is reportedly $83-100 \%$ immunoreactive to S-100 protein [11], S-100 protein-negative melanoma has not been widely studied. Argenyi et al. re-evaluated 17 cases of melanomas that had previously tested negative for S-100 protein, and reassessed 8 of the 17 cases as positive for 
S-100 protein; 4 of the remaining S-100 protein-negative cases were positive for HMB-45 antigen, which is consistent with melanoma [11]. Although misdiagnoses may occur for technical reasons, some melanoma cases do not express S-100 protein at detectable levels. Lee et al. studied IHC patterns of five primary sinonasal melanomas and suggested that melanomas with small-cell morphology may be negative or only focally positive for S-100 protein [12]. Our case is the first presentation of S-100-negative pulmonary melanoma. Owing to the immunophenotypic heterogeneity of melanocytic lesions and the limitations of test technology, test results may require comprehensive evaluation, especially in cases of S-100-negative results for suspected melanoma.

The "paving" sign is characterized by a reticular pattern superimposed on ground-glass opacity in CT images. Pulmonary "paving" lesions are frequently diagnosed as PAP, but Lee Chang Hyun reviewed other possible causes of pulmonary "paving," including Pneumocystis carinii pneumonia, bronchio-alveolar cell carcinoma, sarcoidosis, ARDS, pulmonary hemorrhage syndromes, acute radiation pneumonitis, and drug- induced pneumonitis [13].

Although many diseases can show this particular radiographic imaging style, the relationship between diseases and "paving" patterns has not been widely studied. To examine the associations between "paving" patterns and disease variety, we reviewed all English-language articles by searching MEDLINE (PubMed), EMBASE, and Web of Science for observational studies and case reports through December 2015. Searches were performed independently by two investigators on December 2015, using the following terms: "crazy paving," "paving stone," "paving stones," "flagstone," and "slabstone."

We selected all studies that presented radiographic images of paving patterns. Any type of study design was considered, including case reports. We excluded duplicated reports and cases with pathologically unconfirmed or inaccurate clinical diagnoses. We also excluded literature with no cases based on radiographic images of paving patterns.

We identified 198 articles, of which 116 were excluded for not presenting any clinical radiographic images, and 1 was excluded for reporting the same cases in a different review. Finally, 81 citations were accepted for this review. Of these included studies, 29 were original clinical research, 1 was a review, and 51 were case reports. Collectively, they included 456 cases and, demonstrated more than 30 types of diseases-predominantly PAP (203/457, $44.42 \%)$, viral pneumonia $(85 / 457,18.60 \%)$, exogenous lipoid pneumonia (35/457, $7.66 \%)$, pulmonary alveolar microlithiasis $(12 / 457,2.63 \%)$, and bacterial pneumonia $(28 / 457,6.13 \%$; Table 1$)$.

Most of the 29 original studies were retrospective comparisons of radiographic appearance of different diseases; few reported on "paving" as a sign of different diseases. Johkoh et al. investigated the spectrum of disease associated with "crazy paving," and found 46 patients with 15 identified diseases, including ARDS (8/46, $17.4 \%)$, bacterial pneumonia $(7 / 46,15.2 \%)$, acute interstitial pneumonia (5/46, $10.9 \%)$, PAP $(5 / 46,10.9 \%)$, radiation pneumonitis (3/46, $6.5 \%)$, drug-induced pneumonitis $(3 / 46,6.5 \%)$, pulmonary hemorrhage $(2 / 46,4.3 \%)$, chronic eosinophilic pneumonia $(2 / 46,4.3 \%)$, cardiogenic pulmonary edema (2/46, $4.3 \%)$, usual interstitial pneumonia $(2 / 46,4.3 \%)$, mycoplasma pneumonia $(2 / 46,4.3 \%)$, as well as tuberculosis $(1 / 46,2.2 \%)$, obstructive pneumonitis $(1 / 46,2.2 \%)$, $P$ carinii-induced pneumonia (1/46, $2.2 \%)$, and bronchiolitis obliterans organizing pneumonia $(1 / 46,2.2 \%)$ [14]. Murayama et al. also reviewed 10 patients, including those with P carinii-induced pneumonia and ARDS, pulmonary hemorrhage, radiation pneumonitis, drug-induced pneumonitis, PAP, and usual interstitial pneumonia showing pulmonary "paving," with $\mathrm{P}$ carinii- induced pneumonia being the most common [15].

Pulmonary alveolar proteinosis (including cases found in adults, children, and infants) accounted for $44.42 \%$ (203/457) of all cases we found in the literature. It was by far the most common presentation, followed by viral pneumonia (85/457, $18.60 \%)$, exogenous lipoid pneumonia $(35 / 457,7.66 \%)$, bacterial pneumonia (28/457, $6.13 \%)$, and pulmonary alveolar microlithiasis (12/457, $2.63 \%)$. Among the viral pneumonia cases, influenza virus was the most common pathogen (36 patients), followed by SARS-coronavirus (28 patients), cytomegalovirus (17 patients), human T-cell lymphotropic virus type 1 ( 3 patients), and Hantavirus (1 patient). Although these percentages cannot show precise incidence rates for each disease that can show "paving," they may offer clues to causation.

According to the studies we reviewed (Table 1), more than 40 diseases can reportedly show paving patterns in lung images, including pulmonary nocardiosis, granulomatous mycosis fungoides, pulmonary leptospirosis, hypersensitivity pneumonitis, non-specific interstitial pneumonia, organizing pneumonia, systemic lupus erythematosus, non-classifiable interstitial pneumonia, lymphoma, leukemia, AIDS-related Kaposi sarcoma, pulmonary lymphedema, Niemann-Pick disease, idiopathic pneumonia syndrome after bone marrow transplantation, barium aspiration, squalene aspiration pneumonia, bronchioloalveolar cell carcinoma, noncardiogenic pulmonary edema, thoracic lymphangiectasis, and near drowning, in addition to the diseases mentioned above.

\section{Conclusions}

Here, we describe the first case of pulmonary melanoma in the form of discrete bilateral nodules with a paving pattern, although it is not the first case of pulmonary 
Table 1 Summary of reports of radiographic images of "paving" patterns and pathology results

\begin{tabular}{|c|c|c|}
\hline Diseases & Case no. (pct. ${ }^{a}$ ) & References \\
\hline Pulmonary alveolar proteinosis & $203(44.42 \%)$ & \\
\hline \multirow[t]{30}{*}{ Pulmonary alveolar proteinosis } & 24 & Luo, J., et al. (2014) [16] \\
\hline & 35 & Mehrian, P., et al. (2014) [9] \\
\hline & 14 & Souza, C. A., et al. (2012) [17] \\
\hline & 15 & Ishii, H., et al. (2009) [18] \\
\hline & 8 & Choi, H. K., et al. (2010) [19] \\
\hline & 6 & Spira, D., et al. (2013) [20] \\
\hline & 6 & Cai, X., et al. (2005) [21] \\
\hline & 5 & Coulier, B., et al. (1999) [22] \\
\hline & 5 & Johkoh, T., et al. (1999) [14] \\
\hline & 3 & Ishii, H., et al. (2009) [18] \\
\hline & 3 & Mu, X. D., et al. (2008) [23] \\
\hline & 3 & Akin, M. R. and G. K. Nguyen (2004) [24] \\
\hline & 2 & Oh, S. J., et al. (2014) [25] \\
\hline & 2 & Luo, J., et al. (2013) [26] \\
\hline & 1 & Choi, Y. R., et al. (2015) [27] \\
\hline & 1 & Oda, N., et al. (2015) [28] \\
\hline & 1 & Kinehara, Y., et al. (2014) [29] \\
\hline & 1 & Albores, J., et al. (2013) [30] \\
\hline & 1 & Moisan, M., et al. (2013) [31] \\
\hline & 1 & Langwieler, S., et al. (2012) [32] \\
\hline & 1 & Jayaraman, S., et al. (2010) [33] \\
\hline & 1 & Maimon, N. and D. Heimer (2010) [34] \\
\hline & 1 & Ueda, Y., et al. (2009) [35] \\
\hline & 1 & McDermott, H., et al. (2009) [36] \\
\hline & 1 & Matsunaga, K., et al. (2008) [37] \\
\hline & 1 & Sugimoto, C., et al. (2006) [38] \\
\hline & 1 & De Arriba, C., et al. (2006) [39] \\
\hline & 1 & Collard, B., et al. (2002) [40] \\
\hline & 1 & Yokomura, K., et al. (2002) [41] \\
\hline & 1 & Murayama, S., et al. (1999) [15] \\
\hline \multirow[t]{2}{*}{ Pediatric PAP } & 32 & Enaud, L., et al. (2014) [42] \\
\hline & 22 & Berteloot, L., et al. (2014) [43] \\
\hline \multirow[t]{2}{*}{ Children PAP } & 1 & El-Dawlatly, A., et al. (2011) [44] \\
\hline & 1 & Zontsich, T., et al. (1998) [45] \\
\hline \multirow[t]{8}{*}{ Exogenous lipoid pneumonia } & $35(7.66 \%)$ & \\
\hline & 11 & Marchiori, E., et al. (2010) [46] \\
\hline & 6 & Choi, H. K., et al. (2010) [19] \\
\hline & 6 & Lee, J. Y., et al. (1999) [47] \\
\hline & 5 & Laurent, F., et al. (1999) [48] \\
\hline & 3 & Zanetti, G., et al. (2007) [49] \\
\hline & 1 & Nakashima, S., et al. (2015) [50] \\
\hline & 1 & Schoofs, C., et al. (2010) [51] \\
\hline
\end{tabular}


Table 1 Summary of reports of radiographic images of "paving" patterns and pathology results (Continued)

\begin{tabular}{|c|c|c|}
\hline & 1 & Sias, S. M., et al. (2009) [52] \\
\hline & 1 & Meltzer, E., et al. (2006) [53] \\
\hline Virus pneumonia & $85(18.60 \%)$ & \\
\hline \multirow[t]{2}{*}{ Influenza virus pneumonia } & 11 & Kloth, C., et al. (2015) [54] \\
\hline & 8 & Ono, A., et al. (2014) [55] \\
\hline \multirow[t]{4}{*}{ Influenza A (H1N1) pneumonia } & 11 & Amorim, V. B., et al. (2013) [56] \\
\hline & 4 & Henzler, T., et al. (2010) [57] \\
\hline & 1 & Marchiori, E., et al. (2011) [58] \\
\hline & 1 & Chandler, T. M., et al. (2010) [59] \\
\hline Cytomegalovirus pneumonia & 17 & Kloth, C., et al. (2015) [54] \\
\hline SARS-Coronovirus pneumonia & 28 & Wong, C. K., et al. (2012) [60] \\
\hline Hantavirus pulmonary syndrome & 1 & Goncalves, F. G., et al. (2010) [61] \\
\hline Human T-cell lymphotropic virus type 1 related pneumonia & 3 & Yamashiro, T., et al. (2012) [62] \\
\hline Bacterial pneumonia & $28(6.13 \%)$ & \\
\hline Bacterial pneumonia & 7 & Johkoh, T., et al. (1999) [14] \\
\hline P. aeruginosa pneumonia & 13 & Kloth, C., et al. (2015) [54] \\
\hline \multirow[t]{2}{*}{ Streptococcus pneumoniae pneumonia } & 7 & Ono, A., et al. (2014) [55] \\
\hline & 1 & Ngo, M. H., et al. (2003) [63] \\
\hline \multirow[t]{5}{*}{ Pulmonary alveolar microlithiasis } & $12(2.63 \%)$ & \\
\hline & 9 & Francisco, F. A., et al. (2015) [64] \\
\hline & 1 & McDermott, H., et al. (2009) [36] \\
\hline & 1 & Roca Vanaclocha, Y., et al. (2008) [65] \\
\hline & 1 & Gasparetto, E. L., et al. (2004) [66] \\
\hline Pulmonary nocardiosis & $5(1.09 \%)$ & Tsujimoto, N., et al. (2012) [67] \\
\hline Granulomatous mycosis fungoides & $1(0.22 \%)$ & Sverzellati, N., et al. (2006) [68] \\
\hline \multirow[t]{2}{*}{ Tuberculosis } & $1(0.22 \%)$ & Huang, H. and P. X. Lu (2013) [69] \\
\hline & $1(0.22 \%)$ & Johkoh, T., et al. (1999) [14] \\
\hline Mycoplasma pneumonia & $2(0.44 \%)$ & Johkoh, T., et al. (1999) [14] \\
\hline \multirow[t]{2}{*}{ P carinii-induced pneumonia } & $4(0.88 \%)$ & Murayama, S., et al. (1999) [15] \\
\hline & $1(0.22 \%)$ & Johkoh, T., et al. (1999) [14] \\
\hline \multirow[t]{2}{*}{ Pulmonary Leptospirosis } & $3(0.66 \%)$ & von Ranke, F. M., et al. (2015) [70] \\
\hline & $1(0.22 \%)$ & Marchiori, E., et al. (2008) [71] \\
\hline Obstructive pneumonitis & $1(0.22 \%)$ & Johkoh, T., et al. (1999) [14] \\
\hline \multirow[t]{2}{*}{ ARDS } & $8(1.75 \%)$ & Johkoh, T., et al. (1999) [14] \\
\hline & $1(0.22 \%)$ & Murayama, S., et al. (1999) [15] \\
\hline \multirow[t]{2}{*}{ Pulmonary hemorrhage } & $3(0.66 \%)$ & Johkoh, T., et al. (1999) [14] \\
\hline & $1(0.22 \%)$ & Murayama, S., et al. (1999) [15] \\
\hline Chronic eosinophilic pneumonia & $2(0.44 \%)$ & Johkoh, T., et al. (1999) [14] \\
\hline Hypersensitivity pneumonitis & $1(0.22 \%)$ & Scordino, D. and L. Regan (2014) [72] \\
\hline Interstitial pneumonia & $1(0.22 \%)$ & Chen, G. L., et al. (2014) [73] \\
\hline \multirow[t]{2}{*}{ Usual interstitial pneumonia } & $2(0.44 \%)$ & Johkoh, T., et al. (1999) [14] \\
\hline & $1(0.22 \%)$ & Murayama, S., et al. (1999) [15] \\
\hline Non-specific interstitial pneumonia & $1(0.22 \%)$ & Coche, E., et al. (2001) [74] \\
\hline Acute interstitial pneumonia & $5(1.09 \%)$ & Johkoh, T., et al. (1999) [14] \\
\hline
\end{tabular}


Table 1 Summary of reports of radiographic images of "paving" patterns and pathology results (Continued)

\begin{tabular}{|c|c|c|}
\hline Organizing pneumonia & $1(0.22 \%)$ & Utrilla Contreras, C., et al. (2014) [75] \\
\hline Bronchiolitis obliterans organizing pneumonia & $1(0.22 \%)$ & Johkoh, T., et al. (1999) [14] \\
\hline Systemic lupus erythematosus & $1(0.22 \%)$ & Hisada, T., et al. (2006) [76] \\
\hline Nonclassifiable interstitial pneumonia & $4(0.88 \%)$ & Song, l., et al. (2012) [77] \\
\hline Malignant melanoma metastasis & $1(0.22 \%)$ & Kalchiem-Dekel, O., et al. (2015) [7] \\
\hline Peripheral T-cell lymphoma & $1(0.22 \%)$ & Fraser, T. and A. Nagarur (2015) [78] \\
\hline Adult T-cell leukemia or lymphoma & $4(0.88 \%)$ & Okada, F., et al. (2004) [79] \\
\hline AIDS-related Kaposi sarcoma & $1(0.22 \%)$ & Matsunaga, K., et al. (2008) [37] \\
\hline Pulmonary lymphedema & $1(0.22 \%)$ & Ohnishi, H., et al. (2014) [80] \\
\hline \multirow[t]{3}{*}{ Cardiogenic pulmonary edema } & $2(0.44 \%)$ & Johkoh, T., et al. (1999) [14] \\
\hline & $1(0.22 \%)$ & Senturk, A., et al. (2013) [81] \\
\hline & $1(0.22 \%)$ & Maimon, N., et al. (2006) [82] \\
\hline Niemann-Pick disease & $1(0.22 \%)$ & Castanon Martinez, R., et al. (2012) [83] \\
\hline Idiopathic pneumonia syndrome after bone marrow transplantation & $1(0.22 \%)$ & Gasparetto, T. D., et al. (2008) [84] \\
\hline Barium aspiration & $1(0.22 \%)$ & Akata, S., et al. (2007) [85] \\
\hline \multirow[t]{3}{*}{ Bronchioloalveolar cell carcinoma } & $2(0.44 \%)$ & Que, C. L., et al. (2006) [86] \\
\hline & $1(0.22 \%)$ & Kunimasa, K., et al. (2015) [87] \\
\hline & $1(0.22 \%)$ & Rossi, S. E., et al. (2003) [8] \\
\hline Noncardiogenic pulmonary edema & $1(0.22 \%)$ & Takeshita, T., et al. (2005) [88] \\
\hline Squalene aspiration pneumonia & $8(1.75 \%)$ & Lee, K. H., et al. (2005) [89] \\
\hline Thoracic lymphangiectasis & $1(0.22 \%)$ & Orliaguet, O., et al. (2002) [90] \\
\hline Near drowning & $3(0.66 \%)$ & Kim, K. l., et al. (2000) [91] \\
\hline \multirow[t]{2}{*}{ Radiation pneumonitis } & $3(0.66 \%)$ & Johkoh, T., et al. (1999) [14] \\
\hline & $1(0.22 \%)$ & Murayama, S., et al. (1999) [15] \\
\hline \multirow[t]{2}{*}{ Drug-induced pneumonitis } & $3(0.66 \%)$ & Johkoh, T., et al. (1999) [14] \\
\hline & $1(0.22 \%)$ & Murayama, S., et al. (1999) [15] \\
\hline Total & 457 & \\
\hline
\end{tabular}

${ }^{\text {a }}$ Percentage of reported cases among all cases reviewed above

melanoma with a "crazy paving" imaging, making melanoma another of more than 40 diseases that can appear as paving patterns in chest images. Although paving patterns are rare, physicians should consider pulmonary melanoma in differential diagnoses of patients who display this sign.

\section{Abbreviations}

$C T$, computed tomography; PAP, pulmonary alveolar proteinosis

\section{Acknowledgements}

Not applicable.

\section{Funding}

Not applicable.

\section{Availability of data and materials}

Not applicable.

\section{Authors' contributions}

All authors had access to the data and roles in writing the manuscript. As the principal investigator, HLZ had full access to all the study data and assumes responsibility for the integrity of the data and the accuracy of the analysis. YKF, JPZ, HLZ, and QY contributed to the study's conception, design, and interpretation; YKF and QY obtained the data, documented the case, and performed the literature search; JPZ and HLZ were responsible for screening abstracts, selecting manuscripts for full-text review, and performing the analysis; and WNX, GHZ, YJX, and ZXZ assisted in the successive revisions of the final manuscript; All authors read and approved the final manuscript.

\section{Competing interests}

The authors declare that they have no competing interests.

\section{Consent for publication}

Written informed consent was obtained from a direct relative of the patient for publication of this case report and any accompanying images. A copy of the written consent is available for review by the editor of this journal.

\section{Ethics approval and consent to participate}

This report adhered to the tenets of the Declaration of Helsinki and was approved by the Tongji Hospital ethics committee. Consent to participate in this study was obtained from a direct relative of the patient.

Received: 12 February 2016 Accepted: 26 July 2016

Published online: 03 August 2016 


\section{References}

1. Siegel R, Ma J, Zou Z, et al. Cancer statistics, 2014. CA Cancer J Clin. 2014;64(1):9-29.

2. Kyrgidis A, Tzellos TG, Triaridis S. Melanoma: Stem cells, sun exposure and hallmarks for carcinogenesis, molecular concepts and future clinical implications. J Carcinog. 2010:9:3.

3. Lee YT. Malignant melanoma: pattern of metastasis. CA Cancer J Clin. 1980;30(3):137-42

4. Chen JT, Dahmash NS, Ravin CE, et al. Metastatic melanoma in the thorax: report of 130 patients. AJR Am J Roentgenol. 1981;137(2):293-8.

5. Wilson RW, Moran CA. Primary melanoma of the lung: a clinicopathologic and immunohistochemical study of eight cases. Am J Surg Pathol. 1997:21(10):1196-202.

6. Shin NY, Hong YJ, Kim AH, et al. Diffuse interstitial infiltrative lung metastasis of malignant melanoma: a case report. Korean J Radiol. 2011;12(2):252-5.

7. Kalchiem-Dekel O, Maimon N, Shack AR, et al. An unusual presentation of malignant melanoma metastatic to the lungs and bronchi. Bilateral groundglass opacities with a "crazy paving" component. Am J Respir Crit Care Med. 2015;191(8):954-5.

8. Rossi SE, Erasmus JJ, Volpacchio M, et al. "Crazy-paving" pattern at thinsection CT of the lungs: radiologic-pathologic overview. Radiographics. 2003;23(6):1509-19.

9. Mehrian P, Homayounfar N, Karimi MA, et al. Features of idiopathic pulmonary alveolar proteinosis in high resolution computed tomography. Pol J Radiol. 2014;79:65-9.

10. Jensen OA, Egedorf J. Primary malignant melanoma of the lung. Scand J Respir Dis. 1967;48(2):127-35.

11. Argenyi ZB, Cain C, Bromley C, et al. S-100 protein-negative malignant melanoma: fact or fiction? A light-microscopic and immunohistochemical study. Am J Dermatopathol. 1994;16(3):233-40.

12. Lee $H$, Torres FX, McLean SA, et al. Immunophenotypic heterogeneity of primary sinonasal melanoma with aberrant expression of neuroendocrine markers and calponin. Appl Immunohistochem Mol Morphol. 2011;19(1):48-53.

13. Lee CH. The crazy-paving sign. Radiology. 2007;243(3):905-6.

14. Johkoh T, Itoh H, Muller NL, et al. Crazy-paving appearance at thin-section CT: spectrum of disease and pathologic findings. Radiology. 1999;211(1):155-60.

15. Murayama S, Murakami J, Yabuuchi H, et al. "Crazy paving appearance" on high resolution CT in various diseases. J Comput Assist Tomogr. 1999;23(5):749-52.

16. Luo J, Yang D, Zhou S, et al. Crazy paving pattern caused by pulmonary alveolar proteinosis: CT findings and the pathologic basis. Zhong Nan Da Xue Xue Bao Yi Xue Ban. 2014;39(9):924-9.

17. Souza CA, Marchiori E, Goncalves LP, et al. Comparative study of clinical, pathological and HRCT findings of primary alveolar proteinosis and silicoproteinosis. Eur J Radiol. 2012;81(2):371-8.

18. Ishii $H$, Trapnell BC, Tazawa $R$, et al. Comparative study of high-resolution $C T$ findings between autoimmune and secondary pulmonary alveolar proteinosis. Chest. 2009:136(5):1348-55.

19. Choi HK, Park CM, Goo JM, et al. Pulmonary alveolar proteinosis versus exogenous lipoid pneumonia showing crazy-paving pattern: Comparison of their clinical features and high-resolution CT findings. Acta Radiol. 2010;51(4):407-12.

20. Spira D, Wirths S, Skowronski F, et al. Diffuse alveolar hemorrhage in patients with hematological malignancies: HRCT patterns of pulmonary involvement and disease course. Clin Imaging. 2013:37(4):680-6.

21. Cai X, Zeng QS, Guan YB, et al. Analysis of the imaging findings of pulmonary alveolar proteinosis. Di Yi Jun Yi Da Xue Xue Bao. 2005;25(4):441-3.

22. Coulier B, Mailleux P, Mairesse M, et al. Alveolar proteinosis: signs and prognosis using high-resolution computed tomography in 5 patients. JBRBTR. 1999;82(6):277-81.

23. Mu XD, Nie LG, Wang GF, et al. Idiopathic pulmonary alveolar proteinosis: report of three cases and literature review. Beijing Da Xue Xue Bao. 2008;40(5):551-4.

24. Akin MR, Nguyen GK. Pulmonary alveolar proteinosis. Pathol Res Pract. 2004;200(10):693-8. discussion 699-700.

25. Oh SJ, Choo JY, Lee KY, et al. Localized pulmonary alveolar proteinosis: two case reports. Balkan Med J. 2014;31(3):257-60.

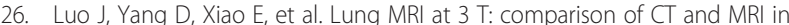
initial evaluation of pulmonary alveolar proteinosis. Zhong Nan Da Xue Xue Bao Yi Xue Ban. 2013:38(11):1160-6.

27. Choi YR, Chang YJ, Kim SW, et al. Crazy paving radiography finding in asymptomatic pulmonary alveolar proteinosis. Asian Cardiovasc Thorac Ann. 2015;23(5):588-90
28. Oda N, Tamai K, Suzuki Y, et al. Marked improvement in autoimmune pulmonary alveolar proteinosis with severe hypoxemia in a patient treated with ambroxol: a case report. J Med Case Rep. 2015;9:100.

29. Kinehara $Y$, Kida H, Inoue $Y$, et al. Development of microscopic polyangiitisrelated pulmonary fibrosis in a patient with autoimmune pulmonary alveolar proteinosis. BMC Pulm Med. 2014;14:172.

30. Albores J, Seki A, Fishbein MC, et al. A rare occurrence of pulmonary alveolar proteinosis after lung transplantation. Semin Respir Crit Care Med. 2013;34(3):431-8.

31. Moisan M, Lafargue M, Calderon J, et al. Pulmonary alveolar proteinosis requiring "hybrid" extracorporeal life support, and complicated by acute necrotizing pneumonia. Ann Fr Anesth Reanim. 2013;32(4):e71-5.

32. Langwieler S, Smektala E, Waldburg N, et al. 45-year old patient with progressive shortness of breath and "crazy paving". Internist (Berl). 2012:53(11):1359-63.

33. Jayaraman S, Gayathri AR, Senthil Kumar P, et al. Whole lung lavage for pulmonary alveolar proteinosis. Lung India. 2010;27(1):33-6.

34. Maimon N, Heimer D. The crazy-paving pattern on computed tomography. CMAJ. 2010:182(14):1545

35. Ueda Y, Matsuo K, Tsushima M, et al. Patient with autoimmune alveolar proteinosis who did not respond to GM-CSF inhalation therapy and underwent repeated whole-lung lavage. Nihon Kokyuki Gakkai Zasshi. 2009;47(9):833-8.

36. McDermott $\mathrm{H}$, Aitchison $\mathrm{F}$, Nathani $\mathrm{N}$, et al. A case report of pulmonary alveolar proteinosis. BMJ Case Rep. 2009;2009.

37. Matsunaga $\mathrm{K}$, Nagata N, Iwata $Y$, et al. Pulmonary alveolar proteinosis noted in a patient with thymoma. Nihon Kokyuki Gakkai Zasshi. 2008;46(6):497-500.

38. Sugimoto C, Kobayashi H, Kanoh S, et al. Radiological findings in initial pulmonary alveolar proteinosis detected in the post-treatment course of nocardiosis. Nihon Kokyuki Gakkai Zasshi. 2006:44(10):738-41.

39. De Arriba C, Anton C, Arreche E, et al. Pulmonary alveolar proteinosis and crazy paving pattern in high resolution CT. An Sist Sanit Navar. 2006;29(1):127-30.

40. Collard B, Cool M, Hertveldt $\mathrm{K}$, et al. Pulmonary alveolar proteinosis. JBR-BTR. 2002;85(5):260-3.

41. Yokomura K, Chida K, Suda T, et al. Secondary pulmonary alveolar proteinosis associated with myelodysplastic syndrome. Nihon Kokyuki Gakkai Zasshi. 2002:40(7):599-604.

42. Enaud L, Hadchouel A, Coulomb A, et al. Pulmonary alveolar proteinosis in children on La Reunion Island: a new inherited disorder? Orphanet J Rare Dis. 2014;9:85

43. Berteloot L, Taam RA, Emond-Gonsard S, et al. Primary pulmonary alveolar proteinosis: computed tomography features at diagnosis. Pediatr Radiol. 2014;44(7):795-802.

44. El-Dawlatly A, Hajjar W, Alnassar S, et al. Continuous positive airway pressure ventilation during whole lung lavage for treatment of alveolar proteinosis A case report and review of literature. Saudi J Anaesth. 2011;5(1):76-8.

45. Zontsich $\mathrm{T}$, Helbich $\mathrm{TH}$, Wojnarovsky $\mathrm{C}$, et al. Pulmonary alveolar proteinosis in a child: HRCT findings before and after bronchoalveolar lavage. Eur Radiol. 1998:8(9):1680-2.

46. Marchiori E, Zanetti G, Mano CM, et al. Lipoid pneumonia in 53 patients after aspiration of mineral oil: comparison of high-resolution computed tomography findings in adults and children. J Comput Assist Tomogr. 2010:34(1):9-12

47. Lee JY, Lee KS, Kim TS, et al. Squalene-induced extrinsic lipoid pneumonia: seria radiologic findings in nine patients. J Comput Assist Tomogr. 1999:23(5):730-5.

48. Laurent F, Philippe JC, Vergier B, et al. Exogenous lipoid pneumonia: HRCT, MR, and pathologic findings. Eur Radiol. 1999;9(6):1190-6.

49. Zanetti G, Marchiori E, Gasparetto TD, et al. Lipoid pneumonia in children following aspiration of mineral oil used in the treatment of constipation: highresolution CT findings in 17 patients. Pediatr Radiol. 2007;37(11):1135-9.

50. Nakashima S, Ishimatsu Y, Hara S, et al. Exogenous lipoid pneumonia successfully treated with bronchoscopic segmental lavage therapy. Respir Care. 2015;60(1):e1-5.

51. Schoofs C, Bladt L, De Wever W. An uncommon cause of asyptomatic crazy paving pattern: exogenous lipoid pneumonia. JBR-BTR. 2010;93(4):228.

52. Sias SM, Ferreira AS, Daltro PA, et al. Evolution of exogenous lipoid pneumonia in children: clinical aspects, radiological aspects and the role of bronchoalveolar lavage. J Bras Pneumol. 2009;35(9):839-45.

53. Meltzer E, Guranda L, Vassilenko L, et al. Lipoid pneumonia: a preventable complication. Isr Med Assoc J. 2006:8(1):33-5.

54. Kloth C, Forler S, Gatidis S, et al. Comparison of chest-CT findings of Influenza virus-associated pneumonia in immunocompetent vs. immunocompromised patients. Eur J Radiol. 2015;84(6):1177-83. 
55. Ono A, Okada F, Takata S, et al. A comparative study of thin-section CT findings between seasonal influenza virus pneumonia and Streptococcus pneumoniae pneumonia. Br J Radiol. 2014;87(1039):20140051.

56. Amorim VB, Rodrigues RS, Barreto MM, et al. Influenza A (H1N1) pneumonia: HRCT findings. J Bras Pneumol. 2013;39(3):323-9.

57. Henzler T, Meyer M, Kalenka A, et al. Image findings of patients with H1N1 virus pneumonia and acute respiratory failure. Acad Radiol. 2010;17(6):681-5.

58. Marchiori E, Zanetti G, D'lppolito G, et al. Crazy-paving pattern on HRCT of patients with H1N1 pneumonia. Eur J Radiol. 2011;80(2):573-5.

59. Chandler TM, Ajlan AM, Muller NL. Case of the month \#165: Swine-origin influenza A (H1N1) viral pneumonia presenting as crazy-paving on computed tomography: case report and literature review. Can Assoc Radiol J. 2010;61(4):241-4.

60. Wong CK, Lai V, Wong YC. Comparison of initial high resolution computed tomography features in viral pneumonia between metapneumovirus infection and severe acute respiratory syndrome. Eur J Radiol. 2012;81(5):1083-7.

61. Goncalves FG, Jovem CL, Isac VM, et al. High-resolution computed tomography findings in hantavirus pulmonary syndrome. J Thorac Imaging. 2010;25(2):W33-5.

62. Yamashiro $T$, Kamiya H, Miyara $T$, et al. CT scans of the chest in carriers of human T-cell lymphotropic virus type 1: presence of interstitial pneumonia. Acad Radiol. 2012;19(8):952-7.

63. Ngo MH, Chen HT, Stark P. Crazy-paving appearance associated with Streptococcus pneumoniae sepsis. Semin Respir Infect. 2003;18(3):220-2.

64. Francisco FA, Rodrigues RS, Barreto MM, et al. Can chest high-resolution computed tomography findings diagnose pulmonary alveolar microlithiasis? Radiol Bras. 2015;48(4):205-10.

65. Roca Vanaclocha Y, Narvaez JA, Pozuelo C, et al. Alveolar microlithiasis: an uncommon cause of the crazy paving pattern. Radiologia. 2008;50(1):75-8.

66. Gasparetto EL, Tazoniero P, Escuissato DL, et al. Pulmonary alveolar microlithiasis presenting with crazy-paving pattern on high resolution $\mathrm{CT}$. $\mathrm{Br}$ J Radiol. 2004;77(923):974-6.

67. Tsujimoto N, Saraya T, Kikuchi K, et al. High-resolution CT findings of patients with pulmonary nocardiosis. J Thorac Dis. 2012;4(6):577-82.

68. Sverzellati N, Poletti V, Chilosi M, et al. The crazy-paving pattern in granulomatous mycosis fungoides: high-resolution computed tomographypathological correlation. J Comput Assist Tomogr. 2006;30(5):843-5.

69. Huang H, Lu PX. Paving-stone CT finding in a pulmonary tuberculosis patient. Quant Imaging Med Surg. 2013;3(5):282-3.

70. von Ranke FM, Zanetti G, Escuissato DL, et al. Pulmonary Leptospirosis With Diffuse Alveolar Hemorrhage: High-Resolution Computed Tomographic Findings in 16 Patients. J Comput Assist Tomogr. 2015.

71. Marchiori E, Gasparetto TD, Escuissato DL, et al. Leptospirosis of the lung presenting with crazy-paving pattern: correlation between the high-resolution CT and pathological findings. Rev Port Pneumol. 2008;14(6):887-91.

72. Scordino D, Regan L. Crazy paving on computed tomography after marijuana use. J Emerg Med. 2014;46(4):e127-9.

73. Chen GL, Wang J, Li BZ, et al. Cutaneous Vasculitis, Interstitial Pneumonia with Crazy-Paving Appearance, and Positive pANCA in a Patient with Severe Crohn's Disease. Case Rep Gastrointest Med. 2014;2014:485714.

74. Coche E, Weynand B, Noirhomme P, et al. Non-specific interstitial pneumonia showing a "crazy paving" pattern on high resolution $\mathrm{CT}$. Br J Radiol. 2001:74(878):189-91.

75. Utrilla Contreras C, Fernandez-Velilla Pena M, Garcia Rio F, et al. Radiographic patterns in the diagnostic approach to organizing pneumonia. Rev Clin Esp (Barc). 2014;214(5):258-65.

76. Hisada T, Ishizuka T, Tomizawa Y, et al. "Crazy-paving" appearance in systemic lupus erythematosus. Intern Med. 2006;45(1):29-30.

77. Song I, Yi CA, Han J, et al. CT findings of late-onset noninfectious pulmonary complications in patients with pathologically proven graftversus-host disease after allogeneic stem cell transplant. AJR Am J Roentgenol. 2012;199(3):581-7.

78. Fraser T, Nagarur A. Pulmonary involvement of peripheral T-cell lymphoma manifesting as crazy paving pattern. Proc (Bayl Univ Med Cent). 2015;28(1):59-61.

79. Okada F, Ando Y, Kondo Y, et al. Thoracic CT findings of adult T-cell leukemia or lymphoma. AJR Am J Roentgenol. 2004;182(3):761-7.

80. Ohnishi H, Yamane T, Shiota N, et al. Life-threatening pulmonary lymphedema secondary to thoracic duct ligation. Intern Med. 2014;53(20):2341-5.

81. Senturk A, Karalezli A, Soyturk AN, et al. A rare cause of crazy-paving and mediastinal lymphadenopathy: congestive heart failure. J Clin Imaging Sci. 2013;3:30
82. Maimon N, Paul N, Downey GP. Progressive dyspnea associated with a crazy-paving appearance on a chest computed tomography scan. Can Respir J. 2006;13(5):269-71.

83. Castanon Martinez R, Fernandez-Velilla Pena M, Gonzalez Montano MV, et al. Lung affectation in an adult patient with Niemann-Pick disease, type B. Arch Bronconeumol. 2012;48(6):213-5.

84. Gasparetto TD, Marchiori E, Guimaraes MB, et al. Idiopathic pneumonia syndrome after bone marrow transplantation presenting with "crazy-paving" pattern on high-resolution computed tomography: a case report. Cases J. 2008;1(1):234.

85. Akata S, Park J, Shindo H, et al. Barium aspiration showing crazy-paving appearance on high-resolution computed tomography. Australas Radiol. 2007:51(Suppl):B235-7.

86. Que $\mathrm{CL}$, Zhang PJ, Wang WH, et al. An analysis of the clinical and radiological features of bronchioloalveolar carcinoma. Zhonghua Jie He He Hu Xi Za Zhi. 2006;29(10):662-4.

87. Kunimasa K, Tachihara M, Terashita T, et al. Gradually Enlarging Crazy-paving Appearance. Intern Med. 2015;54(21):2791-2.

88. Takeshita T, Shima H, Oishi S, et al. Noncardiogenic pulmonary edema as the first manifestation of pheochromocytoma: a case report. Radiat Med. 2005;23(2):133-8.

89. Lee KH, Kim WS, Cheon JE, et al. Squalene aspiration pneumonia in children: radiographic and $C T$ findings as the first clue to diagnosis. Pediatr Radiol. 2005:35(6):619-23.

90. Orliaguet O, Beauclair P, Gavazzi G, et al. Thoracic lymphangiectasis presenting with chyloptysis and bronchial cast expectoration. Eur Radiol. 2002;12 Suppl 3:S162-5.

91. Kim Kl, Lee KN, Tomiyama N, et al. Near drowning: thin-section $\mathrm{CT}$ findings in six patients. J Comput Assist Tomogr. 2000;24(4):562-6.

\section{Submit your next manuscript to BioMed Central and we will help you at every step:}

- We accept pre-submission inquiries

- Our selector tool helps you to find the most relevant journal

- We provide round the clock customer support

- Convenient online submission

- Thorough peer review

- Inclusion in PubMed and all major indexing services

- Maximum visibility for your research

Submit your manuscript at www.biomedcentral.com/submit
) Biomed Central 